\section{SM Journal of Nephrology and Kidney Diseases}

Article Information

Received date: Jun 06, 2017

Accepted date: Jul 04, 2017

Published date: Jul 10, 2017

*Corresponding author

Łukasz Dobrek, Department of

Pathophysiology, Jagiellonian

University Medical College,

Krakow, Poland,

Tel: +48 1263290 56;

Email: lukaszd@mp.pl

Distributed under Creative Commons CC-BY 4.0

Keywords Cyclophosphamide; Ifosfamide; Neutrophil GelatinaseAssociated Lipocalin-1 (NGAL-1)

Abbreviations AKI: acute kidney injury; BUN: blood urea nitrogen; CP: cyclophosphamide; FENa: fractional excretion of sodium; IF: ifosfamide; NGAL-1: neutrophil gelatinaseassociated lipocalin-1; KIM-1: kidney injury molecule-1

Article DOI 10.36876/smjnkd.1002

\section{OPEN ACCESS}

ISSN: 2576-5450

\section{Biochemical and Histological Evaluation of Kidney Function in Rats after a Single Administration of Cyclophosphamide and Ifosfamide}

\author{
Lukasz Dobrek*, Agnieszka Baranowska, Beata Skowron and Piotr Thor \\ Department of Pathophysiology, Jagiellonian University Medical College, Poland
}

\section{Abstract}

Background: Cyclophosphamide (CP) and Ifosfamide (IF) are widely used cytotoxic agents. Both CP and IF exert some characteristic adverse drug reactions including kidney damage taking various clinical forms, depending on the applied dose or administration route. The aim of our study was to estimate kidney function using selected, classical biochemical parameters as well as analyzing the urinary concentration and excretion of a modern "kidney troponin" - neutrophil gelatinase-associated lipocalin-1 (NGAL-1) in rats after administration of a single $\mathrm{CP}$ or IF dose.

Methods: 30 rats were divided into three groups ( $n=10$ each; half males and females): group 1 - control (rats receiving i.p. saline solution); groups 2 and 3 - rats intraperitoneally treated with a single CP or IF dose of 150 $\mathrm{mg} / \mathrm{kg}$ b.w., respectively. Following saline/CP/IF administration, animals were housed in single metabolic cages, to assess 24-hour diuresis and to obtain urinary samples for further laboratory assays. Finally, blood samples were collected and rats were sacrificed to perform autopsy with cystectomy and nephrectomy with subsequent histopathological analysis. Standard parameters of kidney function were assayed either in blood or in urine with an additional assessment of the urine NGAL-1 level.

Results: Single administration of both $\mathrm{CP}$ and IF resulted in decreased $\mathrm{pH}$ of urine and proteinuria accompanied by an increased 24-hour urinary NGAL-1 excretion. Moreover, CP-treated rats demonstrated polyuria. Concentrations and 24-hour excretion of most classical, low-weight parameters were not different in both CP- and IF-treated rats compared to values observed in control animals.

The histopathological analysis in CP/IF treated animals revealed presence of cystic inflammatory lesions and a normal kidney structure, with the exception of a mild to moderate congestive hyperemia.

Conclusion: A single administration of $\mathrm{CP}$ and IF caused a functional kidney tubulopathy in study rats manifested by marked proteinuria with increased 24-hour NGAL-1 urinary excretion.

\section{Introduction}

Cyclophosphamide (CP) and ifosfamide (IF), cytotoxic compounds from the group of oxazaphosphorines, are widely used pharmacological agents. They are used as chemotherapeutic agents for wide spectrum of malignancies, e.g. leukemia, lymphoma, breast, prostate or ovarian cancers. CP is also used as an immunosuppressant in rheumatoid arthritis or in selected forms of nephrotic syndrome [1].

Both CP and IF are associated with several adverse drug reactions: myelosuppression, infections, gastrointestinal and hepatic toxicity, pulmonary fibrosis or neurotoxicity (encephalopathy) [2-5]. Moreover, cyclophosphamide and ifosfamide cause renal and cystic dysfunctions. They result from the fact that both CP and IF are metabolized along pathways producing some similar metabolites. Acrolein, produced mostly in course of CP metabolism, is the causative agent for hemorrhagic cystitis, whereas chloroacetaldehyde, formed primarily in by metabolic changes of IF, induces nephrotoxicity [6].

Acrolein is a highly reactive, unsaturated aldehyde that causes reduction of the intracellular level of glutathione, induces lipid peroxidation and changes the intracellular redox balance. These abnormalities lead to dysregulation of cytokines participating in inflammatory processes, proliferation and apoptosis [7]. Acrolein, filtered in the kidney into urine, induces a cascade of inflammatory changes leading to release of numerous proinflammatory mediators and free radicals that damage the urothelium [8-10]. Chloracetaldehyde intensifies the unfavourable effect of acrolein, primarily causing dysfunction of renal tubules by further reduction of glutathione, acetyl-coenzyme A and ATP levels, and block of the enzymatic complex of the NADH ubiquinone oxidoreductase - a component of the mitochondrial respiratory chain [8]. Moreover, chloracetaldehyde enters renal tubular cells predisposing those renal structures to damage. The amount of chloracetaldehyde produced as a result of IF metabolism is approximately 40 times higher compared to CP, thus 
justifying the common opinion about the high nephrotoxic potential of IF [11].

However, clinical reports demonstrate that both CP and IF share some major side effects, namely: nephrotoxicity and urotoxicity [11]. That is a result of the fact, that acrolein, produced mostly in $\mathrm{CP}$ metabolic pathways, is also synthetized by cytochromes CYP2B6 $[12,13]$ and CYP2C9 [14] located in extrabladder tissues, including the kidneys. Acrolein is also one of the intermediate metabolites released in course of the metabolism of IF. Acrolein causes an increased oxidative stress and, according to reports, plays an important role in CP-induced kidney damage [15].

Therefore, the application of both CP/IF is associated with the increased risk of kidney damage.

A variety of methods are available to assess function and injuries of the kidney. Besides imaging methods (USG, tomography), there are also laboratory tests evaluating the excretory and regulative functions of the kidney. They include classic laboratory measurement of creatinine, blood urea nitrogen, proteinuria, and secondary, calculated parameters, such as: creatinine clearance, fractional excretion of sodium, Renal Failure Index (RFI), important for the diagnosis and differentiation of many kidney disorders e.g. Acute Kidney Injury (AKI) [16]. At present, the biochemical diagnostics of renal function is increasingly based on modern biomarkers, allowing the measurement of glomerular filtration (e.g. cystatin C, $\beta-2$ microglobulin, $\beta$-trace protein), the assessment of kidney - tubular, interstitial or glomerular injury (urinary kidney injury molecule-1; KIM-1, neutrophil gelatinase-associated lipocalin-1; NGAL-1, $\mathrm{N}$-acetyl- $\beta$-D-glucosaminidase, liver-type fatty acid binding protein; LFABP, nephrin, podocin), or confirmation of renal fibrosis (growth factors, tenascin, matrixmetalloproteinases) in a more reliable manner compared to classical parameters. Also, parameters for causative assessment of renal disease, such as oxidative stress markers (advanced lipoxidation end products, malondialdehyde) or distorted immune responses (chemokines, inflammatory cytokines, cell adhesion molecules), are currently being investigated [16-18].

The detailed description of nephrotoxicity of oxazaphosphorines is still fragmentary and mostly based on the analysis of selected, classical biochemical parameters, whereas, the current laboratory evaluation of renal function should be based on modern renal "troponin" biomarkers, characterized by significantly improved sensitivity and dynamics of renal injury detection.

Therefore, the aim of the study was to assess the nephrotoxic effect using a panel of selected low-weight classical laboratory parameters in plasma and urine, and the urinary analysis of one of the novel kidney function biomarkers - neutrophil gelatinase-associated lipocalin-1-in rats, following a single administration of two cytostatic oxazaphosphorines: cyclophosphamide and ifosfamide.

\section{Materials and Methods}

The medical experiment described in the manuscript was approved by the $1^{\text {st }}$ Local Ethical Committee of the Institute of Pharmacology, Polish Academy of Sciences in Krakow. The experiment was carried out in accordance with both the Directive 2010/63/EU on the protection of animals used for scientific purposes and with the Polish Act of 15 January 2015 on the protection of animals used for scientific or educational purposes (Journal of Laws, February 26, 2015, Pos.266).

\section{Animals and general design of the experiment}

Thirty 12-weeks old albino Wistar rats were used in the study (males and females in equal proportions; with mean body weight $249[\mathrm{~g}])$. Upon arrival at the local Animal House of the Department of Pathophysiology, the animals were quarantined for 10 days to acclimatize to new living conditions. During that period rats were housed in separate sex cages. Then the animals were randomly assigned to three groups $(\mathrm{n}=10$ each): 1 - control, 2 - animals treated with cyclophosphamide, 3 - animals treated with ifosfamide. After administration of a single CP/IF dose (group 2 and 3, respectively) or of physiological saline (group 1), rats were monitored for 24 hours in single metabolic cages to assess their 24-hour diuresis and to obtain urine samples for further biochemical assays. All animals survived the full 24 hour monitoring period following administration of normal saline/CP/IF. Finally, under general anesthesia (pentobaribital, 60 $\mathrm{mg} / \mathrm{kg}$ b.w.), blood samples were collected and finally animals were sacrificed by overdose of the same anesthetic agent (pentobaribital, $200 \mathrm{mg} / \mathrm{kg}$ b.w.) for the general autopsy (including cystectomy and nephrectomy) to provide tissue for histopathological examination and for blood collection.

\section{Drug doses}

In the group 2, rats received a single, $150 \mathrm{mg} / \mathrm{kg}$ intraperitoneal dose of cyclophosphamide, and animals in the group 3 , received the same intraperitoneal dose of ifosfamide. Control animals from the group 1 received a single intraperitoneal dose of normal saline in similar volumes to those used in groups 1 and 2. Cyclophosphamide and ifosfamide injections were prepared ex-tempore prior to the administration to individual subjects. Selection of the CP dose of 150 $\mathrm{mg} / \mathrm{kg}$ b.w. was consistent with literature data, recommending a single administration of $100 \mathrm{mg} / \mathrm{kg}$ b.w. [19], $150 \mathrm{mg} / \mathrm{kg}$ b.w. [20,21], or 200 $\mathrm{mg} / \mathrm{kg}$ b.w. [22,23] as the amount causing a sub-lethal toxic (including nephrotoxic) effect in rats. On the same basis, the recommended single nephrotoxic dose of IF used for experimental purposes ranged between 60-240 in rabbits [24] to as much as $400 \mathrm{mg} / \mathrm{kg}$ b.w. in mice [25]. Also, consistently to our previous experiments, adoption of the selected dosage regimen resulted in acute urinary bladder injury developed within 4 - 24h following CP/IF administration [26,27].

\section{The monitoring in metabolic cages}

After administration of saline/CP/IF in groups 1-3, respectively, animals were placed in individual metabolic cages for a 24-hour urine collection, with free and unlimited access to water and food. The following parameters were analyzed: 24 -hour diuresis [mL/24h] and basic vital and housing parameters: 24 -hour water $[\mathrm{mL} / 24 \mathrm{~h}]$ and feed $[\mathrm{g} / 24 \mathrm{~h}]$ intake, body mass $[\mathrm{g}]$ and temperature $\left[{ }^{\circ} \mathrm{C}\right]$. Moreover, using the commercially available strips for qualitative and semi-quantitative analysis of urine (ACON LABORATORIES), urine $\mathrm{pH}$, Specific Gravity (SG), presence of blood and leukocytes were also assessed. The presence of blood was assessed using the semi-quantitative scale provided by the test strip manufacturer: $(-),( \pm),(+),(++),(+++), 5-10$ $[\mathrm{RBCs} / \mu \mathrm{l}]$ or above $50[\mathrm{RBCs} / \mu \mathrm{l}]$. Similarly,leukocytes were assessed using a recommended scale as $(-),(15 \pm[\mathrm{WBCs} / \mu \mathrm{l}]),(70+[\mathrm{WBCs} / \mu \mathrm{l}])$, $(125++[\mathrm{WBCs} / \mu \mathrm{l}]),(500+++[\mathrm{WBCs} / \mu \mathrm{l}])$. 


\section{Biochemical assays in blood}

Immediately after collection, blood was centrifuged to obtain serum (HERAEUS INSTRUMENTS MEGAFUGE 1.0 R, $2000 \mathrm{rpm}$ - $719 \mathrm{~g}$ for $5 \mathrm{~min}$ ). Basic parameters of renal functions: sodium $(\mathrm{Na})$, potassium $(\mathrm{K})$ and urea $[\mathrm{mmol} / \mathrm{L}]$, along with uric acid and creatinine $(\mathrm{Cr})[\mu \mathrm{mol} / \mathrm{L}]$ concentrations were assayed in samples from all study groups, using the ADVIA 1200 SIEMENS analyzer. Also, measurement of daily diuresis value and urinary concentrations allowed calculation of creatinine clearance $\left(\mathrm{CL}_{\mathrm{cr}}\right)$, and urea clearance $\left(\mathrm{CL}_{\text {urea }}\right)$, as well as fractional excretion of sodium $\left(\mathrm{FE}_{\mathrm{Na}}\right)$, according to the following formulas:

$$
\begin{aligned}
& \mathrm{CL}_{\mathrm{cr}}=\left(\mathrm{Cr} \text { urine }[\mu \mathrm{mol} / \mathrm{L}]^{*} \text { diuresis }[\mathrm{mL} / \mathrm{min}]\right) /(\mathrm{Cr} \text { plasma } \\
& {[\mu \mathrm{mol} / \mathrm{L}]) } \\
& \mathrm{CL}_{\text {urea }}=\left(\text { Urea urine }[\mathrm{mmol} / \mathrm{L}]{ }^{*} \text { diuresis }[\mathrm{mL} / \mathrm{min}]\right) /(\text { Urea } \\
&\text { plasma }[\mathrm{mmol} / \mathrm{L}]) \\
& \mathrm{FE}_{\mathrm{Na}}=\left(\left[\left(\mathrm{Na} \text { urine }[\mathrm{mmol} / \mathrm{L}]{ }^{*} \mathrm{Cr} \text { plasma }[(\mu \mathrm{mol}) / \mathrm{L}]\right)^{*} 100\right]\right) / \\
&\left(\mathrm{Na} \text { plasma }[\mathrm{mmol} / \mathrm{L}]{ }^{*} \mathrm{Cr} \text { urine }[(\mu \mathrm{mol}) / \mathrm{L}]\right)
\end{aligned}
$$

The urea concentration was used for the calculation of blood urea nitrogen - BUN according to the formula:

$\mathrm{BUN}=($ Urea plasma $[\mathrm{mg} / \mathrm{dL}]) / 2.1428$

\section{Biochemical assays in urine}

urea $[\mathrm{mmol} / \mathrm{L}]$, uric acid and creatinine $[\mu \mathrm{mol} / \mathrm{L}]$ concentrations were assayed in obtained urine samples, with the ADVIA 1200 SIEMENS analyzer. Also, 24-hour sodium, potassium and urea $[\mathrm{mmol} / 24 \mathrm{~h}]$, uric acid and creatinine $[\mu \mathrm{mol} / 24 \mathrm{~h}]$ excretions were calculated based on the daily diuresis value. Total protein concentration $[\mathrm{g} / \mathrm{L}]$ was assessed as well, and 24 -hour proteinuria value was determined $[\mathrm{mg} / 24 \mathrm{~h}]$.

The urinary concentration of NGAL-1 was also determined using the ELISA method (BIOPORTO DIAGNOSTICS Rat NGAL ELISA kit 046), strictly according to manufacturer's procedure. In the next step, NGAL-1 concentrations resulted from ELISA assay, were re-calculated to the 24-hour urinary excretion in the study groups, similarly to low-weight, classical parameters excretion

\section{Autopsy of animals and histopathological examination of kidneys and urinary bladders}

After monitoring in metabolic cages, animals were sacrificed by overdose of the anesthetic agent. Initially, an anesthetic dose of pentobarbital $(60 \mathrm{mg} / \mathrm{kg}$ b.w.) was administrated to induce a state of deep general anesthesia enabling the removal of fur and the execution of thoracotomy to take blood from the heart for further biochemical assays. Then, additional, large, lethal dose of pentobarbital (200 $\mathrm{mg} / \mathrm{kg}$ b.w.) was administered. After the cessation of vital signs, an autopsy was performed including a gross assessment of abdominal organs to reveal potential, cytotoxic, oxazaphosphorine-induced damage. Bladder and kidney specimens (hematoxylin-eosin stained) were made from tissues collected from sacrificed animals. Details of the histopathological procedure are reported in one of our previously published papers [29].
The histological analysis was performed by a specialist of pathomorphology using an optical (light) microscope (DELTA OPTICAL) under the magnification of 40x (urinary bladders) and 100x (kidneys). Microscopic images were taken using a DLT-Cam Basic 2MP microscopic camera and DLTCamViewer software.

\section{Statistical analysis}

Intergroup differences in values of parameters obtained in study groups were analyzed, comparing the group 1 (control) to the group 2 (CP-treated) and the group 1 (control) to the group 3 (IF-treated). Results of vital/housing parameters and results of blood compounds determinations indicated their normal distribution in all analyzed groups ( $\mathrm{p}$ in Shapiro-Wilk test above 0.05 ), so the final statistical analysis was performed using the t-Student's test. Contrary to the abovementioned finding, parameters determined in urine did not demonstrate the normal distribution in the analyzed groups ( $p$ in Shapiro-Wilk test below 0.05), therefore the final statistical analysis was performed using the Mann-Whitney's test. The statistical analysis was performed using GNU operating system and the R project for statistical computing and graphics (R 3.3.1. package).

\section{Results}

Measurements during monitoring in metabolic cages: The body weight of study animals did not differ significantly between groups. Both CP- and IF-treated animals demonstrated a significantly lower body temperature compared to the control. The adverse reaction to cytotoxic CP and IF was a dramatically lower 24-hour food intake by rats in groups 2 and 3, compared to control animals. The 24-hour water intake was comparable in control animals and CP-treated rats, but significantly lower in rats treated with IF. Despite the significantly decreased 24-hour water intake, IF-treated animals demonstrated a similar diuresis to control ones. On the contrary, CP-treated rats demonstrated about 3-times higher 24-hour urine excretion compared to the control group.

Detailed results of those parameters are shown in the Table 1.

\section{Blood analysis results}

\begin{tabular}{|c|c|c|c|c|c|}
\hline & \multirow{2}{*}{$\begin{array}{l}\text { Control } \\
\text { rats } \\
\text { Group } 1\end{array}$} & \multirow{2}{*}{$\begin{array}{c}\text { CP-treated } \\
\text { rats } \\
\text { Group } 2\end{array}$} & \multirow{2}{*}{$\begin{array}{l}\text { IF-treated } \\
\text { rats } \\
\text { Group } 3\end{array}$} & \multicolumn{2}{|c|}{$\begin{array}{c}\text { Statistical analysis } \\
\text { (p value) }\end{array}$} \\
\hline & & & & $\begin{array}{c}\text { Group } \\
1-2\end{array}$ & $\begin{array}{c}\text { Group } \\
1-3\end{array}$ \\
\hline $\begin{array}{l}\text { body weight } \\
\text { [g] }\end{array}$ & $\begin{array}{l}226.66 \\
\pm 48.89\end{array}$ & $\begin{array}{l}261.02 \\
\pm 53.83\end{array}$ & $\begin{array}{r}259.50 \\
\pm 15.61\end{array}$ & NS & NS \\
\hline $\begin{array}{l}\text { body } \\
\text { temperature } \\
{\left[{ }^{\circ} \mathrm{C}\right]}\end{array}$ & $\begin{array}{l}37.43 \\
\pm 0.93\end{array}$ & $\begin{array}{r}36.23 \\
\pm 0.89\end{array}$ & $\begin{array}{r}36.50 \\
\pm 0.25\end{array}$ & 0.04 & 0.01 \\
\hline $\begin{array}{l}\text { 24-hour water } \\
\text { intake } \\
{[\mathrm{mL} / 24 \mathrm{~h}]}\end{array}$ & $\begin{array}{l}26.34 \\
\pm 4.07\end{array}$ & $\begin{array}{c}22.50 \\
\pm 11.47\end{array}$ & $\begin{array}{r}13.50 \\
\pm 7.19\end{array}$ & NS & 0.01 \\
\hline $\begin{array}{l}\text { 24-hour feed } \\
\text { intake } \\
{[\mathrm{g} / 24 \mathrm{~h}]}\end{array}$ & $\begin{array}{l}23.75 \\
\pm 6.16\end{array}$ & $\begin{array}{c}1.98 \\
\pm 1.37\end{array}$ & $\begin{array}{c}4.53 \\
\pm 3.72\end{array}$ & $<0.001$ & $<0.001$ \\
\hline $\begin{array}{l}\text { 24-hour urine } \\
\text { excretion } \\
\text { [mL/24h] }\end{array}$ & $\begin{array}{c}5.85 \\
\pm 2.37\end{array}$ & $\begin{array}{r}16.70 \\
\pm 8.31\end{array}$ & $\begin{array}{c}8.95 \\
\pm 6,49\end{array}$ & 0.04 & NS \\
\hline
\end{tabular}

Due to a hemolysis present in some samples, we abandoned the assay of potassium. Animals treated with a single CP dose demonstrated a statistically significantly higher serum urea (and

Table 1: Measurements during monitoring in metabolic cages (mean values \pm standard deviations; NS - non-significant). 
Table 2: Blood analysis results and calculated coefficients (mean values \pm standard deviations; NS - non-significant)

\begin{tabular}{|c|c|c|c|c|c|}
\hline & \multirow{2}{*}{$\begin{array}{c}\text { Control } \\
\text { rats }\end{array}$} & \multirow{2}{*}{$\begin{array}{c}\text { CP-treated } \\
\text { rats } \\
\text { Group } 2\end{array}$} & \multirow{2}{*}{$\begin{array}{c}\text { IF-treated } \\
\text { rats } \\
\text { Group } 3\end{array}$} & \multicolumn{2}{|c|}{$\begin{array}{l}\text { Statistic } \\
\text { p value }\end{array}$} \\
\hline & & & & $\begin{array}{c}\text { Group } \\
1-2\end{array}$ & $\begin{array}{c}\text { Group } \\
1-3\end{array}$ \\
\hline $\begin{array}{l}\text { sodium } \\
{[\mathrm{mmol} / \mathrm{L}]}\end{array}$ & $\begin{array}{l}142.06 \\
\pm 1.79\end{array}$ & $\begin{array}{l}141.95 \\
\pm 1.26\end{array}$ & $\begin{array}{l}143.75 \\
\pm 1.95\end{array}$ & NS & NS \\
\hline $\begin{array}{l}\text { urea } \\
\text { [mmol/L] }\end{array}$ & $\begin{array}{c}6.34 \\
\pm 0.75\end{array}$ & $\begin{array}{c}8.97 \\
\pm 1.54\end{array}$ & $\begin{array}{r}10.93 \\
\pm 2.12\end{array}$ & 0.03 & $<0.001$ \\
\hline $\begin{array}{l}\text { uric acid } \\
{[\mu \mathrm{mol} / \mathrm{L}]}\end{array}$ & $\begin{array}{r}157.96 \\
\pm 35.14\end{array}$ & $\begin{array}{r}165.82 \\
\pm 45.77\end{array}$ & $\begin{array}{r}78.38 \\
\pm 21.88 \\
\end{array}$ & NS & 0.002 \\
\hline $\begin{array}{l}\text { creatinine } \\
{[\mu \mathrm{mol} / \mathrm{L}]}\end{array}$ & $\begin{array}{r}28.85 \\
\pm 1.77\end{array}$ & $\begin{array}{r}38.45 \\
\pm 7.96\end{array}$ & $\begin{array}{r}34.67 \\
\pm 7.48\end{array}$ & NS & NS \\
\hline $\begin{array}{l}\text { creatinine } \\
\text { clearance }\end{array}$ & $\begin{array}{c}0.85 \\
\pm 0.34\end{array}$ & $\begin{array}{c}0.91 \\
\pm 0.25\end{array}$ & $\begin{array}{c}0.85 \\
\pm 0.24\end{array}$ & NS & NS \\
\hline urea clearance & $\begin{array}{c}0.65 \\
\pm 0.33\end{array}$ & $\begin{array}{c}0.49 \\
\pm 0.11\end{array}$ & $\begin{array}{c}0.38 \\
\pm 0.10\end{array}$ & NS & NS \\
\hline $\mathrm{FE}_{\mathrm{Na}}$ & $\begin{array}{c}0.42 \\
\pm 0.07\end{array}$ & $\begin{array}{c}0.41 \\
\pm 0.20\end{array}$ & $\begin{array}{c}0.32 \\
\pm 0.07\end{array}$ & NS & NS \\
\hline BUN & $\begin{array}{r}17.76 \\
\pm 2.10\end{array}$ & $\begin{array}{l}25.16 \\
\pm 4.31\end{array}$ & $\begin{array}{r}30.62 \\
\pm 5.93\end{array}$ & 0.02 & 0.009 \\
\hline
\end{tabular}

$\mathrm{FE}_{\mathrm{Na}}$ - Fractional excretion of sodium, BUN - blood nitrogen urea.

BUN) levels compared to the control ones; other measured parameters were comparable in both groups. Rats receiving a single IF dose also demonstrated a higher serum urea (and BUN) levels, but - contrary to animals treated with $\mathrm{CP}$ - a significantly lower uric acid concentration was observed in their case, compared to control subjects. Other differences were not statistically significant.

Detailed numerical values of parameters discussed above are presented in the Table 2 .

\section{Urinalysis results}

The qualitative and semi-quantitative analysis of urine performed using urinary strips indicated a significant $\mathrm{pH}$ drop in $\mathrm{CP}$-treated animals, accompanied by the presence of blood estimated as $(+)$ or $(++)$ and of leukocytes assessed as $15 \pm$ or $70+[\mathrm{WBCs} / \mu \mathrm{l}]$. Also, significantly lower concentrations of urea, uric acid and creatinine were found in those rats compared to control ones. The CP

Table 3: Urinalysis results (mean values \pm standard deviations; NS - nonsignificant).

\begin{tabular}{|c|c|c|c|c|c|}
\hline & \multirow{2}{*}{$\begin{array}{c}\text { Control rats } \\
\text { Group } 1\end{array}$} & \multirow{2}{*}{$\begin{array}{c}\text { CP-treated rats } \\
\text { Group } 2\end{array}$} & \multirow{2}{*}{$\begin{array}{l}\text { IF-treated rats } \\
\text { Group } 3\end{array}$} & \multicolumn{2}{|c|}{$\begin{array}{l}\text { Statistic } \\
\text { p value }\end{array}$} \\
\hline & & & & $\begin{array}{c}\text { Group } \\
1-2\end{array}$ & $\begin{array}{c}\text { Group } \\
1-3\end{array}$ \\
\hline pH & $\begin{array}{c}8.94 \\
\pm 0.17\end{array}$ & $\begin{array}{c}6.75 \\
\pm 0.29\end{array}$ & $\begin{array}{c}6.13 \\
\pm 0.75\end{array}$ & $<0.001$ & 0.002 \\
\hline SG & $\begin{array}{c}1.011 \\
\pm 0.002 \\
\end{array}$ & $\begin{array}{c}1.014 \\
\pm 0.003\end{array}$ & $\begin{array}{c}1.023 \\
\pm 0.006\end{array}$ & NS & 0.02 \\
\hline $\begin{array}{l}\text { urea } \\
\text { [mmol/L] }\end{array}$ & $\begin{array}{r}1003.96 \\
\pm 188.91\end{array}$ & $\begin{array}{c}414.35 \\
\pm 115.32\end{array}$ & $\begin{array}{c}949.25 \\
\pm 532.44\end{array}$ & $<0.001$ & NS \\
\hline $\begin{array}{l}\text { uric acid } \\
{[\mu \mathrm{mol} / \mathrm{L}]}\end{array}$ & $\begin{array}{r}1286.54 \\
\pm 296.59\end{array}$ & $\begin{array}{c}826.18 \\
\pm 321.76\end{array}$ & $\begin{array}{r}1378.10 \\
\pm 401.61\end{array}$ & 0.03 & NS \\
\hline $\begin{array}{l}\text { creatinine } \\
{[\mu \mathrm{mol} / \mathrm{L}]}\end{array}$ & $\begin{array}{c}6100.00 \\
\pm 1099.35\end{array}$ & $\begin{array}{c}3350.00 \\
\pm 1173.31\end{array}$ & $\begin{array}{c}6750.00 \\
\pm 4340.89\end{array}$ & 0.004 & NS \\
\hline $\begin{array}{l}\text { protein } \\
\text { [g/L] }\end{array}$ & $\begin{array}{c}0.81 \\
\pm 0.51\end{array}$ & $\begin{array}{c}2.51 \\
\pm 0.92\end{array}$ & $\begin{array}{c}3.91 \\
\pm 3.15\end{array}$ & 0.01 & NS \\
\hline $\begin{array}{l}\text { NGAL-1 } \\
{[n g / m L]}\end{array}$ & $\begin{array}{c}0.97 \\
\pm 0.32\end{array}$ & $\begin{array}{c}1.49 \\
\pm 1.32\end{array}$ & $\begin{array}{c}2.48 \\
\pm 1.87\end{array}$ & NS & 0.004 \\
\hline
\end{tabular}

SG - specific gravity, NGAL-1 - neutrophil gelatinase-associated lipocalin-1.
Table 4: 24-hour urinary excretion (mean values \pm standard deviations; NS non-significant).

\begin{tabular}{|c|c|c|c|c|c|}
\hline & \multirow{2}{*}{$\begin{array}{c}\text { Control rats } \\
\text { Group } 1\end{array}$} & \multirow{2}{*}{$\begin{array}{c}\text { CP-treated rats } \\
\text { Group } 2\end{array}$} & \multirow{2}{*}{$\begin{array}{c}\text { IF-treated rats } \\
\text { Group } 3\end{array}$} & \multicolumn{2}{|c|}{$\begin{array}{l}\text { Statistic } \\
\text { p value }\end{array}$} \\
\hline & & & & $\begin{array}{c}\text { Group } \\
1-2\end{array}$ & $\begin{array}{c}\text { Group } \\
1-3\end{array}$ \\
\hline $\begin{array}{l}\text { urea } \\
{[\mathrm{mmol} / 24 \mathrm{~h}]}\end{array}$ & $\begin{array}{c}5.80 \\
\pm 2.38\end{array}$ & $\begin{array}{c}6.36 \\
\pm 1.91\end{array}$ & $\begin{array}{c}5.72 \\
\pm 0.61\end{array}$ & NS & NS \\
\hline $\begin{array}{l}\text { uric acid } \\
{[\mu \mathrm{mol} / 24 \mathrm{~h}]}\end{array}$ & $\begin{array}{c}7.49 \\
\pm 3.75\end{array}$ & $\begin{array}{r}13.53 \\
\pm 6.82\end{array}$ & $\begin{array}{r}10.58 \\
\pm 5.36\end{array}$ & NS & NS \\
\hline $\begin{array}{l}\text { creatinine } \\
{[\mu \mathrm{mol} / 24 \mathrm{~h}]}\end{array}$ & $\begin{array}{c}35.19 \\
\pm 13.85\end{array}$ & $\begin{array}{c}50.49 \\
\pm 18.12\end{array}$ & $\begin{array}{c}42.21 \\
\pm 13.76\end{array}$ & NS & NS \\
\hline $\begin{array}{l}\text { protein } \\
{[\mathrm{mg} / 24 \mathrm{~h}]}\end{array}$ & $\begin{array}{c}5.27 \\
\pm 4.47\end{array}$ & $\begin{array}{c}38.70 \\
\pm 17.12\end{array}$ & $\begin{array}{c}23.57 \\
\pm 14.83\end{array}$ & 0.004 & 0.03 \\
\hline
\end{tabular}

administration resulted in a significantly higher urinary protein concentration.

Rats treated with a single IF dose, similarly to those ones treated with $\mathrm{CP}$, demonstrated a significant acidification of the urine, blood presence estimated as $( \pm)$ or $(+)$ and leucocyturia similar to that observed in the group 1. Even higher urinary protein content was found in IF-treated rats. The increase of urinary protein was also consistently associated with a statistically significant increase in urinary specific gravity in that group compared to the control one.

The urinary concentration of NGAL-1 in CP treated animals was not significantly different from the value determined in control animals, while IF- treated rats demonstrated almost 2.5 times higher urinary NGAL-1 concentration compared to control.

Detailed results of the parameters discussed above are presented in the Table 3.

Analysis of the 24-hour excretion of selected parameters with urine revealed that the higher total urinary protein concentration in CP-treated animals was also accompanied by significantly increased 24-hour urinary protein excretion in those animals. The excretion of the other parameters (urea, uric acid, creatinine) was not significantly different from values observed in the control group.

A similar relationship was found in the analysis of 24-hour urine excretion in IF-treated animals.

Detailed values of the parameters discussed above are presented in the Table 4.

The 24-hour urinary NGAL-1 excretion in both CP- and IFtreated rats was significantly higher compared to control animals. Rats treated with IF demonstrated almost 3-fold $(15.42 \pm 9.23$ [ng/24h]; $\mathrm{p}=0.001)$, while CP-treated animals almost 5-fold (27.19 \pm 21.23 [ng/24h]; $\mathrm{p}=0.007)$ growth of 24 -hour NGAL-1urinary excretion compared to the control $(5.7 \pm 2.98[\mathrm{ng} / 24 \mathrm{~h}])$.

Findings mentioned above are presented in the Figure 1.

\section{The histopathological analysis}

During the autopsy, no gross gastrointestinal or lung abnormalities were observed that could result from the $\mathrm{CP} / \mathrm{IF}$ cytotoxic effects. In urinary bladder specimens of animals treated with both CP and IF, inflammatory infiltration and hyperemia with the local hemorrhagic changes were observed. The urothelium lining demonstrated signs of exfoliation and regeneration. Kidneys of animals from both groups 2 and 3 were mildly or moderately congested. However, the general 


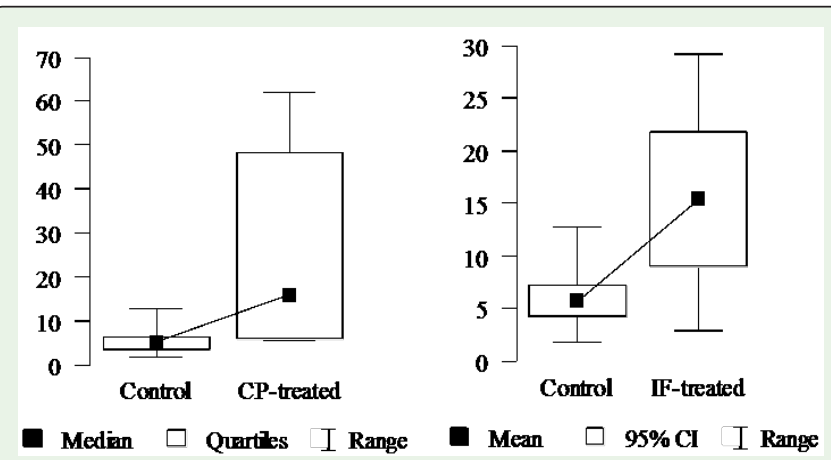

Figure 1: The 24-hour urinary NGAL-1 excretion [ng/24h] in CP-treated (left) and IF-treated (right) rats; $p=0.007$ for CP-treated rats, $p=0.001$ for IF-treated ones.

histological assessment of kidneys was within the normal view established on the basis of the analysis of specimens collected from control animals.

Examples of histopathological images of urinary bladders and kidneys collected from study animals are shown in Figures 2 and 3.

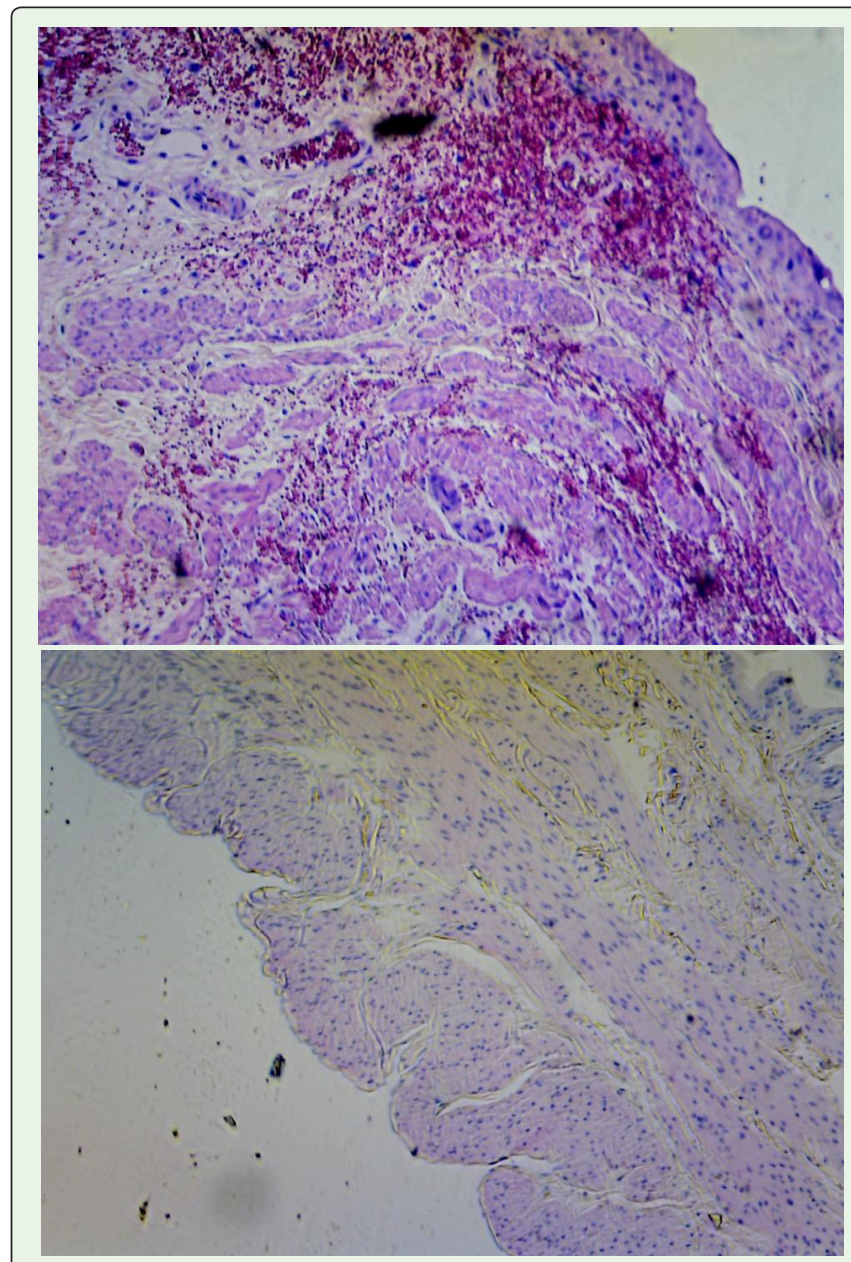

Figure 2: Microscopic imaging of the urinary bladders - in control (lower part) and in the CP/IF (upper part) rats.

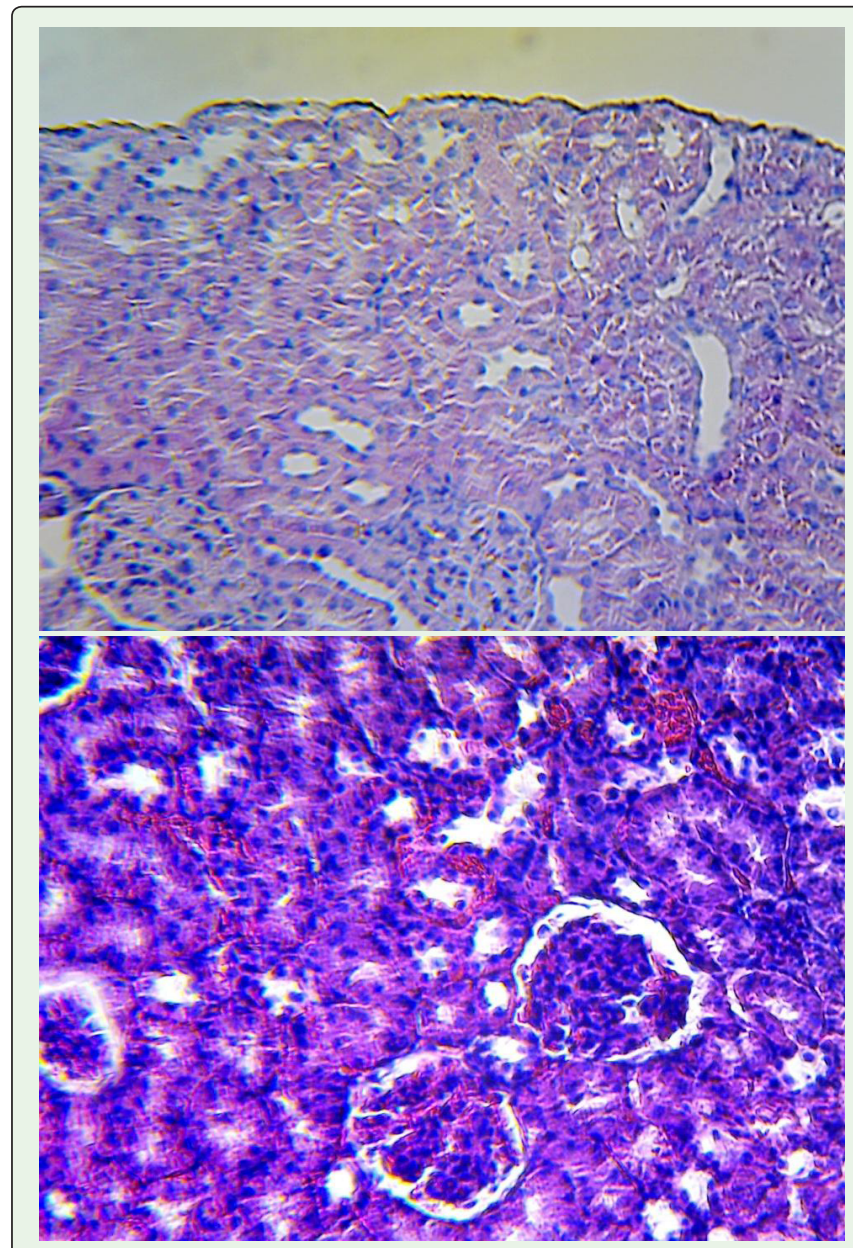

Figure 3: Microscopic imaging of the kidneys - in control (upper part) and in the CP/IF (lower part) rats.

\section{Discussion}

Main findings of the results described above may be summed up:

1. A single administration of cyclophosphamide at the dose of 150 $\mathrm{mg} / \mathrm{kg}$ b.w. resulted in a significant polyuria (accompanied by normal 24-hour water intake), decreased urine $\mathrm{pH}$ and marked general proteinuria. Moreover, $\mathrm{CP}$-treated rats demonstrated an increased 24-hour urinary NGAL-1 excretion. Those animals demonstrated an increased blood urea and BUN concentrations, accompanied by decreased urinary levels of those compounds, with an additional decrease of urinary uric acid and creatinine levels. However, the quantitative 24-hour urinary excretion of the above mentioned compounds did not differ from the values observed in control animals.

The histopathological analysis revealed presence of inflammatory lesions in urinary bladders, and normal structure of kidneys, with the exception of slight congestive hyperemia.

2. A single administration of ifosfamide at the dose of $150 \mathrm{mg} / \mathrm{kg}$ b.w., resulted in the 24-hour diuresis comparable to the control group. However, similarly to $\mathrm{CP}$ administration, a significant proteinuria and $\mathrm{pH}$ decrease were observed. The urinary NGAL-1 concentration 
as well as the 24-hour urinary excretion of the biomarker were significantly higher in IF-treated animals compared to control ones. A higher blood urea and BUN were found, and a decreased blood uric acid level. On the other hand, however, the 24-hour urinary excretion of those compounds (and creatinine) was comparable to the values observed in the control group. As in the case of CP-treated animals, bladder inflammatory lesions, and a generally normal presentation of kidney tissues (with the exception of a mild or moderate congestion) were found in rats receiving a single IF dose.

The analysis of basic, classical biochemical parameters used for evaluation of the kidney function showed no significant disturbances in CP/IF-treated animals. The only significant abnormality was a higher urea (and BUN) concentration in blood of those animals. However, the 24-hour urinary urea excretion in those animals was not higher compared to control rats. Results of the creatinine concentration (along with calculated creatinine clearance and the 24hour urinary creatinine excretion) and fractional sodium excretion were also comparable to the control group. Therefore, results of those laboratory parameters, routinely determined in assessment of the kidney function, did not suggest the existence of a significant renal dysfunction following a single CP/IF dose. Those results are partially consistent with the Rehman et al. study [28], which showed that a single peritoneal administration of $\mathrm{CP}$ in mice caused only an increase of BUN and creatinine levels. Unfortunately, those authors did not estimate any novel nephrological biomarkers, so the comparison of NGAL-1 results was impossible.

In our opinion, the most important finding from our experiment was the demonstration of increased 24-hour urinary excretion of NGAL-1 in rats following administration of a single dose of either CP or IF. NGAL-1 is a protein belonging to the family of lipocalins. The protein possesses a characteristic tertiary, spatial structure that accepts the shape of a barrel with a hydrophobic inner calyx, allowing binding of lipophilic structures (fatty acids, retinoids, arachidonic acid and prostanoids, steroids) $[29,30]$. Primary ligands for NGAL-1 are siderophores - small, non-peptide molecules ( $1 \mathrm{kDa}$ or less), binding $\mathrm{Fe}^{3+}$ ions [31]. Cells that have a particularly rich content of NGAL-1 are neutrophils, monocytes/macrophages and adipocytes and organs endowed with the ability to produce and secrete NGAL-1 are: kidney, prostate, bone marrow, lung, salivary glands, stomach, colon or liver [31,32]. NGAL-1 is also secreted in inflammatory conditions and cancers [32]. The protein has several biological functions related to its most important feature - the ability to transport iron. NGAL-1, as a donor of the element, participates in kidney embryogenesis because iron is essential in cell proliferation and differentiation processes. NGAL-1 promotes epithelial differentiation of mesynchemal progenitors to glomeruli, proximal and distal tubules and the Henle's loop [33]. The protein is also over expressed in many cancers, participating in epithelial neoplastic transition. Moreover, NGAL1 binds matrixmetalloproteinase-9, protecting it from enzymatic degradation, therefore enabling cancer progression, angiogenesis and metastasis by degradation of the extracellular matrix [32]. As a chelator of iron, NGAL-1 is an inhibitor of bacterial growth and a causative factor of secondary anemia. Depletion of intracellular bacterial iron stores results in antibacterial effect, and reduced delivery of iron to the bone marrow inhibits the erythropoiesis process [34,35]. Also, NGAL-dependent iron deprivation is the mechanism of apoptosis of B-cells [36].
For diagnostic purposes, NGAL-1 is recognized as one of the most useful biomarkers of ischemic or toxic renal injury. NGAL1 elevation precedes the elevation of the classical biochemical parameters of kidney damage, such as creatinine [29-32]. In our opinion, that premise also applies to our experiment. Kidney damage occurring as a result of administration of oxazaphosphorines is manifested by increased urinary excretion of NGAL-1, without accompanying hypercreatininemia. Lipocalin-1 is freely filtered into the primary urine and in physiological conditions it is resorbed by proximal tubules via the megalin receptor-mediated mechanism $[37,38]$. In our study, the filtration process assessed by evaluation of plasma creatinine level, 24-hour urinary excretion of creatinine, and calculated creatinine clearance can be considered normal. Therefore, increased urinary NGAL-1 excretion may theoretically be a result of insufficient reabsorption of the filtered load, due to dysfunction of proximal tubules, or may be caused by increased secretion of NGAL1 by distal tubules resulting from their CP/IF-induced damage [32]. In fact, NGAL-1 secretion increases in response to distal tubular damage induced by hypoxia, prostaglandin F2 $\alpha$, fibroblast growth factors, cytokines like TNF- $\alpha$ and interleukin $1 \beta$ and other noxious factors [30]. Therefore, in our opinion, the above mentioned mechanisms justify the hypothesis that $\mathrm{CP} / \mathrm{IF}$ may be causative agents of tubulopathy (resulting in impairment of resorption and/or excessive secretion), manifested by the demonstrated increase of the urinary NGAL excretion.

The abovementioned NGAL-1 results, suggesting development of renal tubulopathy, must be discussed in the context of urine $\mathrm{pH}$ and the value of diurnal urine excretion. Generally, urine $\mathrm{pH}$ is established along the entire length of renal tubules; however, the proximal segment is the place of reuptake of alkalis, and secretion of $\mathrm{H}^{+}$ions via the antiport $\mathrm{K}^{+} / \mathrm{H}^{+}$- ATPase and by the luminal pump $\mathrm{H}^{+}$- ATPase into urine takes place in the distal tubules. The final $\mathrm{pH}$ of urine depends also on the phosphate and ammonia buffer [39-41]. An abnormal final urine $\mathrm{pH}$ in $\mathrm{CP} / \mathrm{IF}$-treated rats may be another, indirect evidence of disturbed tubular function, previously manifested by urinary NGAL-1 abnormalities. Moreover, CP-treated rats demonstrated a significant polyuria despite the unchanged 24hour water intake. The finding also supports the hypothesis of CPinduced kidney tubulopathy, as the final concentration of urine through resorption of "free water" takes place in distal tubules, and the process is regulated by $\mathrm{ADH}$-induced aquaporins. On the other hand, however, our observation regarding the $\mathrm{CP}$-induced polyuria is inconsistent with reports suggesting oliguria resulting from hyponatremia due to impaired water excretion following a $\mathrm{CP}$ treatment (although the effect was transient and disappeared after discontinuation of the therapy) [42]. Also, Kim et al. [43] demonstrated in their study that in rat's kidney cyclophosphamide may activate V2 receptors in the absence of vasopressin which leads to increased expression of aquaporin-2, resulting in water retention. Therefore, polyuria demonstrated in our experiment was contrary to the syndrome of inappropriate ADH secretion (SIADH) observed by Kim et al. [43]. Therefore, evaluation of daily urine excretion after cyclophosphamide requires further research to obtain a more definite assessment of the impact of $\mathrm{CP}$ on the diuresis.

Another potential argument supporting the hypothesis of $\mathrm{CP} /$ IF - induced tubular dysfunction in study rats is the finding of a significant proteinuria. According to the basic pathophysiological 
classification of the proteinuria, the phenomenon may be classified as pre-renal, renal or post-renal. The pre-renal ("overload") proteinuria results from the excessive amount low-weight proteins in plasma, freely filtered into urine and exceeding the resorption capacity of the tubules. The renal- glomerular proteinuria results from damage and leakage of the glomerular barrier, whereas renal - tubular one is conditioned by a loss of ability to reabsorb the filtered into urine proteins. The post-renal- inflammatory proteinuria is due to increased secretion of proteins in the urinary tract in the inflammatory entities $[44,45]$.

Taking into account the correct results of classical parameters for glomerular filtration (plasma creatinine concentration, creatinine clearance, 24-hour urinary creatinine excretion), the lack of histopathological features of glomerular damage and the presence of only slight leukocyturia detected in treated animals (which essentially excludes lower urinary tract infection), the excessive proteinuria may be considered a result of impaired function of tubules. The statement, along with the finding of abnormally low urinary $\mathrm{pH}$, would strongly support the kidney tubulopathy hypothesis.

Summing up, the analysis of 24-hour NGAL-1 urinary excretion and demonstration of abnormal urine $\mathrm{pH}$ with increased proteinuria suggest existence of a renal dysfunction in the form of tubulopathy. It should be also mentioned that the suggested disturbances fulfill the criteria of functional disorder, because the histological analysis revealed no significant abnormalities that could be causative factors for the observed biochemical abnormalities. It is also possible that histopathological changes would have occurred later and increased NGAL-1 urinary excretion preceded those potential changes. That assumption would be consistent with the concept of NGAL-1 as the earliest marker of clinically latent stage of kidney damage.

One of the main limitations of our hypothesis of the CP/IFevoked renal functional tubulopathy is that we did not evaluate the plasma concentration of NGAL-1. Meanwhile, one of the potential reasons explaining the increased urinary amount of the protein may be an increased NGAL-1 synthesis in extra-renal tissues, as a result of a generalized inflammation and a generalized CP/IF cytotoxic effect. Therefore, increased urinary NGAL-1 excretion could also be due to the "overload proteinuria". On the other hand, however, in our opinion, the remaining premises regarding $\mathrm{pH}$ and diuresis abnormalities along with absence of any evidence of organ damage detectable on the autopsy are likely to be hypothesized as tubulopathy following a single $\mathrm{CP} / \mathrm{IF}$ administration in rats.

\section{References}

1. Khan TS, Sundin A, Juhlin C, Wilander E, Oberg K, Eriksson B. Vincristine cisplatin, teniposide and cyclophosphamide combination in the treatment of recurrent or metastatic adrenocortical cancer. Med Oncol. 2004; 21: 167-177.

2. Haubitz M. Acute and long-term toxicity of cyclophosphamide. Tx Med. 2007; 19: $26-31$.

3. Khan JA, Shahdad S, Makhdoomi MA, Hamid S, Bhat GM, Jan Y, et al. Effect of cyclophosphamide on the microanatomy of liver of albino rats. Int J Res Med Sci. 2014; 2: 1466-1469

4. Tascilar M, Loos WJ, Seynaeve C, Verweij J, Sleijfer S. The pharmacologic basis of ifosfamide use in adult patients with advanced soft tissue sarcomas. Oncologist 2007; 12: 1351-1360.

5. Newton HB. Neurological complications of chemotherapy to the central nervous system. HandbClin Neurol. 2012; 105: 903-916.
6. Zhang J, Tian Q, Zhou SF. Clinical pharmacology of cyclophosphamide and ifosfamide. Curr Drug Ther. 2006; 1: 55-84

7. Kehrer JP, Biswal SS. The molecular effects of acrolein.Toxicol Sci. 2000; 57: 6-15.

8. Sloderbach A , Górska A, Sikorska M, Misiura K, Hładoń B Klasyczneoksazafosforinany - metabolizmiwłaściwościterapeutyczne noweimplikacje (Classical oxazaphosphorines - metabolism and therapeutic properties - new implications). PostepyHig Med Dosw (online). 2013; 67: $1235-1253$ (in polish)

9. Korkmaz A, Kurt B, Yildirim I, Basal S, Topal T, Sadir S, et al. Effects of poly(ADP-ribose) polymerase inhibition in bladder damage caused by cyclophosphamide in rats.ExpBiol Med (Maywood). 2008; 233: 338-343.

10. Korkmaz A, Topal T, Oter S. Pathophysiological aspects of cyclophosphamide and ifosfamide induced hemorrhagic cystitis; implication of reactive oxygen and nitrogen species as well as PARP activation. Cell BiolToxicol. 2007; 23: 303-312.

11. Perazella MA. Onco-nephrology: renal toxicities of chemotherapeutic agents. Clin J Am SocNephrol. 2012; 7: 1713-1721.

12. Knights KM, Rowland A, Miners JO. Renal drug metabolism in humans: the potential for drug-endobiotic interactions involving cytochrome P450 (CYP) and UDP glucuronosyltransferase (UGT). Br J ClinPharmacol. 2013; 76: 587 602.

13. Wang H, Tompkins LM. CYP2B6: new insights into a historically overlooked cytochrome P450 isozyme.Curr Drug Metab. 2008; 9: 598-610.

14. Johansson M, Strahm E, Rane A, Ekstrom L. CYP2C8 and CYP2C9 mRNA expression profile in the human fetus. Front Genet. 2014; 5: 58.

15. Amien Al, Fahmy SR, Abd-Elgleel FM, Elaskalany SM. Renoprotective effect of Mangiferaindica polysaccharides and silymarin against cyclophosphamide toxicity in rats. JoBAZ 2015; 72: 154-162.

16. Ferguson MA, Waikar SS. Established and emerging markers of kidney function. Clin Chem. 2012; 58: 680-689.

17. Urbschat A, Obermuller N, Haferkamp A. Biomarkers of kidney injury. Biomarkers 2011; 16: S22-S30.

18. Tesch GH. Serum and urine biomarkers of kidney disease: a pathophysiological perspective. Nephrology (Carlton) 2010; 15: 609-616.

19. Ayhanci A, Gunes S, Sahinturk V, Appak S, Uyar R, Cengiz M, et al. Seleno L-methionine acts on cyclophosphamide-induced kidney toxicity. BiolTrace Elem Res. 2010; 136: 171-179.

20. Sinanoglu O, Yener AN, Ekici S, Midi A, Aksungar FB. The protective effects of spirulina in cyclophosphamide induced nephrotoxicity and urotoxicity in rats.Urology 2012; 80: 1392 e1-6.

21. Abraham $P$, Isaac $B$. The effects of oral glutamine on cyclophosphamideinduced nephrotoxicity in rats. Hum ExpToxicol. 2011; 30: 616-623.

22. Sayed-Ahmed MM. Progression of cyclophosphamide-induced acute renal metabolic damage in carnitine-depleted rat model.ClinExpNephrol. 2010; 14: 418-426.

23. Mansour HH, El Kiki SM, Hasan HF. Protective effect of N-acetylcysteine on cyclophosphamide-induced cardiotoxicity in rats. Environ ToxicolPharmacol. 2015; 40: 417-422

24. Ypsilantis P, Papaioannou N, Psalla D, Politou M, Simopoulos C. Effects of single dose administration of ifosfamide on testes and semen characteristics in the rabbit.ReprodToxicol. 2003; 17: 237-245.

25. Mota JM, Brito GA, Loiola RT, Cunha FQ, Ribeiro RA. Re: Interleukin-11 attenuates ifosfamide-induced hemorrhagic cystitis. IntBraz J Urol. 2007; 33: 704-710.

26. Dobrek $Ł$, Skowron B, Baranowska A, Malska-Woźniak A, Thor P. Urinary kidney injury molecule-1 (KIM-1) excretion in rats with experimental cystitis induced by oxazaphosphorines. Prz Lek. 2016; 73: 805-812. 
27. Dobrek $Ł$, Skowron B, Baranowska A. Ciesielczyk K, Kopańska K, et al. Nephrotoxicity of a single dose of cyclophosphamide and ifosfamide in rats. Acta Pol Pharm. 2017

28. Rehman MU, Tahir M, Qamar W, Lateef A, Khan R, Quaiyoom A, et al. Cyclophosphamide-induced nephrotoxicity, genotoxicity and damage in kidney genomic DNA of Swiss albino mice: the protective effect of Ellagic acid. Mol Cell Biochem. 2012; 365: 119-127.

29. Devarajan P. Neutrophil gelatinase-associated lipocalin - an emerging troponin for kidney injury. Nephrol Dial Transplant. 2008; 23: 3737-3743.

30. Mori K, Nakao K. Neutrophil gelatinase-associated lipocalin as the real-time indicator of active kidney damage. Kidney Int. 2007; 71: 967-970.

31. Soni SS, Cruz D, Bobek I, Chionh CY, Nalesso F, Lentini P, et al. NGAL: a biomarker of acute kidney injury and other systemic conditions. IntUrolNephrol. 2010; 42: 141-150.

32. Makris K, Rizos D, Kafkas N, Haliassos A. Neutrophil gelatinase-associated lipocalin as a new biomarker in laboratory medicine. ClinChem Lab Med. 2012; 50: 1519-1532

33. Yang J, Goetz D, Li JY, Wang W, Mori K, Setlik D, et al. An iron delivery pathway mediated by lipocalin. Mol Cell. 2002; 10: 1045-1056.

34. Goetz DH, Holmes MA, Borregaard N, Bluhm ME, Raymond KN, Strong RK The neutrophil lipocalin NGAL is a bacteriostatic agent that interferes with siderophore-mediated iron acquisition. Mol Cell 2002; 10: 1033-1043.

35. Miharada K, Hiroyama T, Sudo K, Nagasawa T, Nakamura Y. Lipocalin 2 functions as a negative regulator of red cell production in an autocrine fashion. FASEB J. 2005; 19: 1881-1883.
36. Devireddy LR, Gazin C, Zhu X, Green MR. A cell-surface receptor for lipocalin 24 p3 selectively mediates apoptosis and iron uptake. Cell 2005; 123: 1293 1305.

37. Schmidt-Ott KM, Mori K, Jau YL, Kalandadze A, Cohen DJ, Devarajan P, et al. Dual action of neutrophil gelatinase-associated lipocalin. J Am SocNephol. 2007; 18: 407-413.

38. Moestrup SK, Verroust PJ. Megalin- and cubulin-mediated endocytosis of protein-bound vitamins, lipids and hormones in polarized epithelia. Annu Rev Nutr. 2001; 21: 407-428.

39. Roth KS, Chan JCM. Renal tubular acidosis: a new look at an old problem. ClinPediatr (Phila). 2001; 40: 533-543.

40. Soriano JR. Renal tubular acidosis: the clinical entity. J Am SocNephrol. 2002; 13: 2160-2170.

41. Bagga A, Sinha A. Evaluation of renal tubular acidosis. Indian J Pediatr. 2007; 74: 679-686

42. Singh NP, Ganguli A, Prakash A. Drug-induced kidney diseases. J Assoc Physicians India 2003; 51: 970-979.

43. Kim S, Choi HJ, Jo CH, Park JS, Kwon TH, Kim GH. Cyclophosphamideinduced vasopressin-independent activation of aquaporin-2 in the rat kidney. Am J Physiol Renal Physiol. 2015; 309: 474-483.

44. Venkat KK. Proteinuria and microalbuminuria in adults: significance, evaluation and treatment. South Med J. 2004; 97: 969-979.

45. Kashif W, Siddiqi N, Dincer HE, Dincer AP, Hirsch S. Proteinuria: how to evaluate an important finding. CleveClin J Med. 2003; 70: 535-547. 